\title{
First description of male Philometra thaiensis Moravec, Fiala et Dyková, 2004 (Nematoda: Philometridae) from the body cavity of the eyespot pufferfish Tetraodon biocellatus Tirant, and evolutionary relationships of this species with other dracunculoids as inferred from SSU rRNA gene sequences
}

\author{
K. M. A. QUIAZON ${ }^{1,2}$, T. YOSHINAGA ${ }^{1,2^{*}}$, H. DOI $^{3}$, J. ARAKI $^{4}$, K. OGAWA $^{4}$
}

\begin{abstract}
${ }^{1}$ Freshwater Aquaculture Center and College of Fisheries, Central Luzon State University, Science City of Muñoz, Nueva Ecija 3120, Philippines; ${ }^{2}$ Department of Aquatic Bioscience, Graduate School of Agricultural and Life Sciences, The University of Tokyo, Yayoi 1-1-1, Bunkyo-ku, Tokyo 113-8657, Japan, "E-mail:atyoshi@mail.ecc.u-tokyo.ac.jp; ${ }^{3}$ Simonoseki Marine Science Museum, Arcaport 6-1, Shimonoseki, Yamaguchi Prefecture 750-0036, Japan; ${ }^{4}$ Meguro Parasitological Museum, Shimomeguro 4-1-1, Meguro-ku, Tokyo 153-0064, Japan
\end{abstract}

\begin{abstract}
Summary
Finding male philometrid nematodes is essential for taxonomic identification among congeneric species. In this study, male Philometra thaiensis Moravec, Fiala et Dyková, 2004 were collected and described for the first time, from the body cavity of the freshwater fish (eyespot pufferfish) Tetraodon biocellatus Tirant (Tetraodontiformes, Tetraodontidae), and conspecific females were redescribed based on the additional morphological biometrics examined. Molecular examination was carried out on the small subunit $18 \mathrm{~S}$ rRNA, revealing the evolutionary relationships of $P$. thaiensis and reported philometrid species (Philometra and Philometroides) from Japan with other dracunculoids deposited in the GenBank. Based on the molecular data, there are some genera (Philometra, Philometroides, Clavinema, and Margolisianum [genus inquiren$d u m]$ ) requiring further morphological re-evaluation that should be supported with molecular data.
\end{abstract}

Keywords: Philometra thaiensis; Tetraodon biocellatus; eyespot pufferfish; small subunit 18S rRNA; Philometra; Philometroides

\section{Introduction}

Philometrid nematodes (Philometridae) are pathogenic parasites infecting different body parts of freshwater, brackish-water, and marine fishes (Moravec, 2006). With the remarkable size difference between the tiny males (up to $12 \mathrm{~mm}$ for Philometra katsuwoni Petter et Baudin-Laurencin, 1986) (Moravec, 2006) and large gravid females (up to $530 \mathrm{~mm}$ for Philometroides seriolae [Ishii, 1931] (Quiazon et al., 2010)), most of the identified species are known only from female specimens. Currently, there are
29 philometrid species in Asia (including Piscinema barakense Gambhir et $\mathrm{Ng}, 2014$ [species inquirendum]) that infect freshwater fishes (from 6 genera: Clavinema Yamaguti, 1935; Dentiphilometra González-Solís, Moravec et Tuz Paredes, 2007; Dentirumai Quiazon et Moravec, 2012; Philometra Costa, 1845; Philometroides Yamaguti, 1935; Piscinema Gambhir et $\mathrm{Ng}, 2014$ [genus inquirendum]) and 45 species that infect marine and brackish-water fishes (from 7 genera: Buckleyella Rasheed, 1963; Clavinema; Clavinemoides Moravec, Khosheghbal et Pazooki, 2013; Paraphilometroides Moravec et Shaharom-Harrison, 1989; Philometra; Philometroides; and Spirophilometra Parukhin, 1971) (Gambhir \& Ng, 2014; Moravec, 2014; Moravec \& de Buron, 2013; Moravec et al., 2013; Moravec \& Ali, 2014; Quiazon \& Yoshinaga, 2013).

Philometrid nematodes affecting fish reproduction belong to the genus Philometra. In Japan, the discovery of males of the gonad-infecting $P$. lateolabracis (Yamaguti, 1935) from the type host and locality resulted in further re-identifications of many previously misidentified $P$. lateolabracis from the other host fishes (Quiazon et al., 2008a; Moravec \& de Buron, 2013). The morphological differences among males compared to females are very useful for species identification, especially among congeneric species. Apart from $P$. lateolabracis, Quiazon et al. (2008a,b) also described for the first time, the male of $P$. nemipteri Luo, 2001, and based on male morphology, they re-described P. sciaenae Yamaguti, 1941 and established three new species, $P$. madai Quiazon, Yoshinaga et Ogawa, 2008, P. isaki Quiazon, Yoshinaga et Ogawa, 2008, and P. sawara Quiazon, Yoshinaga et Ogawa, 2008. The muscle-infecting philometrid Philometroides seriolae (Ishii, 1931) from the Japanese amberjack Seriola quinqueradiata Temminck et 
Schlegel has also been recently redescribed from available females by Quiazon et al. (2010). In Japan, the species Philometra thaiensis Moravec, Fiala et Dyková, 2004 was raised based solely on gravid female specimens collected from the abdominal cavity of two freshwater Tetraodon species, T. palembangensis Bleeker (type host) and $T$. fluviatilis Hamilton (Tetraodontiformes, Tetraodontidae) after their import from Thailand into the Czech Republic (Moravec et al., 2004). Unfortunately, the male has remained unknown until now.

Understanding the philometrid taxonomy through molecular approaches has not yet been fully explored. Wijová et al. (2006) performed pioneering research by providing phylogenetic analysis focusing on dracunculoid nematodes by using small subunit rRNA (SSU rRNA), although Wu et al. (2005) made a preliminary study on the phylogeny of 9 species of philometrids in China. Afterward, the number of molecularly examined genera (Afrophilometra Moravec, Charo-Karisa et Jirků, 2009; Alinema Rasheed, 1963; Caranginema Moravec, Montoya-Mendoza et Salgado-Maldonado, 2008; Dentiphilometra; Margolisianum Blaylock et Overstreet, 1999 [genus inquirendum]; Nilonema Khalil, 1960; Philometra; Philometroides; and Rumai Travassos, 1960) and species have increased (Černotíková et al., 2011; de Buron et al., 2011; Nadler et al., 2007; Quiazon et al., 2008a,b, 2013; van Megen et al., 2009). However, the examined gene region among these studies varies from SSU rRNA to the ITS region (ITS1-5.8S-ITS2) (Quiazon et al., 2008a,b) and cytochrome oxidase subunit 1 (de Buron et al., 2011).

Parasitological examination of an ornamental freshwater fish, the eyespot pufferfish Tetraodon biocellatus Tirant (Tetraodontiformes, Tetraodontidae), imported from Thailand into Japan in November 2011 and April 2012, succeeded in collecting tiny male and large female nematodes of the genus Philometra from the abdominal cavity of the fish. With the collection of possible male and female $P$. thaiensis and with available samples of gonad-infecting (Philometra spp.) and muscle-infecting (Philometroides seriolae) philometrids isolated from marine fishes off Japan by Quiazon et al. (2008a,b, 2010), molecular analyses on the SSU 18S rRNA gene sequences of these nematode were conducted to reveal their evolutionary relationships with other dracunculoids available in the GenBank.

\section{Material and methods}

The below philometrid specimens were isolated from different host fishes: Philometra species from the abdominal cavity of the eyespot pufferfish $T$. biocellatus (imported from Thailand to Japan as an aquarium fish) (Fig. 1A); Philometra species from the gonads of the Japanese seaperch Lateolabrax japonicus (Cuvier) (Perciformes, Lateolabracidae) (P. lateolabracis), red seabream Pagrus major (Temminck et Schlegel) (Perciformes, Sparidae) ( $P$. madai), Japanese Spanish mackerel Scomberomorus niphonius (Cuvier) (Perciformes, Scombridae) (P. sawara), golden threadfin bream Nemipterus virgatus (Houttuyn)
(Perciformes, Nemipteridae) ( $P$. nemipteri), and silver croaker Pennahia argentata (Houttuyn) (Perciformes, Sciaenidae) (P. sciaenae); and Philometroides seriolae from the body muscles of the Japanese amberjack $S$. quinqueradiata (Perciformes, Carangidae). Only the samples isolated from eyespot pufferfish were subjected to detailed morphological examinations using light microscopy (LM) and scanning electron microscopy (SEM), followed by molecular examination, whereas philometrid samples previously reported by Quiazon et al. (2008a,b, 2010) were directly processed for molecular examination.

\section{Morphological studies}

The collected nematodes were washed in a physiological saline solution, followed by fixing in $70 \%$ ethanol. Both LM and SEM were used for morphological examinations. For LM examination, the $70 \%$ ethanol-fixed samples were cleared in glycerin, followed by mounting of the whole individual nematode on a glass slide. Some morphological features difficult to study by LM were examined using SEM. Briefly, the $70 \%$ ethanol-fixed specimens were post-fixed in $1.25-1.50 \%$ glutaraldehyde, post-fixed in $1 \%$ osmium tetroxide (in phosphate buffer), and dehydrated through a series of ascending ethanol concentrations. Samples were subjected to three changes of absolute butyl alcohol and freeze-dried. Freeze-dried samples were subsequently sputter coated with gold and observed under a scanning electron microscope (SEM S-4000, Hitachi, Japan) at an accelerating voltage of $10 \mathrm{kV}$. Drawings of the nematodes were made with the aid of an Olympus photomicroscope (Olympus, Tokyo, Japan) and computer software (CorelDRAW® Graphics Suite - Version 12.0). Voucher specimens were deposited at the Meguro Parasitological Museum, Tokyo (M.P.M. Coll. No. 20901). All measurements are in micrometres unless otherwise stated. The fish names follow FishBase (Froese and Pauly, 2014).

\section{Molecular studies}

The genomic DNA of five samples of $99.5 \%$ ethanol-fixed worms (1 male and 4 females) was extracted using a DNeasy $^{\text {TM }}$ Tissue Kit (Qiagen, Hilden, Germany) (protocol for animal tissues). Amplification of the SSU 18S rRNA gene was carried out using forward primer $\mathrm{D}-1 \mathrm{~F}$ (5'GCCTATAATGGTGAAACCGCGAAC-3') and reverse primer D-1R (5'-CCGGTTCAAGCCACTG CGATTA-3') (Wijová et al., 2006). The PCR assay was performed with $1 \mu \mathrm{L}$ sample of DNA as a template in a total volume of $20 \mu \mathrm{L}$ that contained $0.6 \mu \mathrm{L}$ forward and reverse primers, 14.1 $\mu \mathrm{L}$ DDW, and $3.7 \mu \mathrm{L}$ Taq mix (containing $0.1 \mu \mathrm{L}$ TAKARA Ex Taq ${ }^{\mathrm{TM}} \mathrm{HS} ; 2 \mu \mathrm{L}[10 \times]$ Ex Taq Buffer; and $48 \mu \mathrm{L}$ dNTP mixture) (Takara Bio Inc., Otsu, Japan). PCR was performed using an iCycler ${ }^{\mathrm{TM}}$ (Bio-Rad Laboratories, Tokyo, Japan) following previously described methods $(6$ cycles of $95{ }^{\circ} \mathrm{C}$ for $1 \mathrm{~min}, 44^{\circ} \mathrm{C}$ for $1 \mathrm{~min}$, and $72{ }^{\circ} \mathrm{C}$ for $2 \mathrm{~min}$, followed by 24 cycles with the annealing temperature increased to $48^{\circ} \mathrm{C}$ ) (Wijová et al., 2006). All sequencing reactions were carried out using the BigDye terminator kit version 3.1 and resolved with an $\mathrm{ABI}$ 

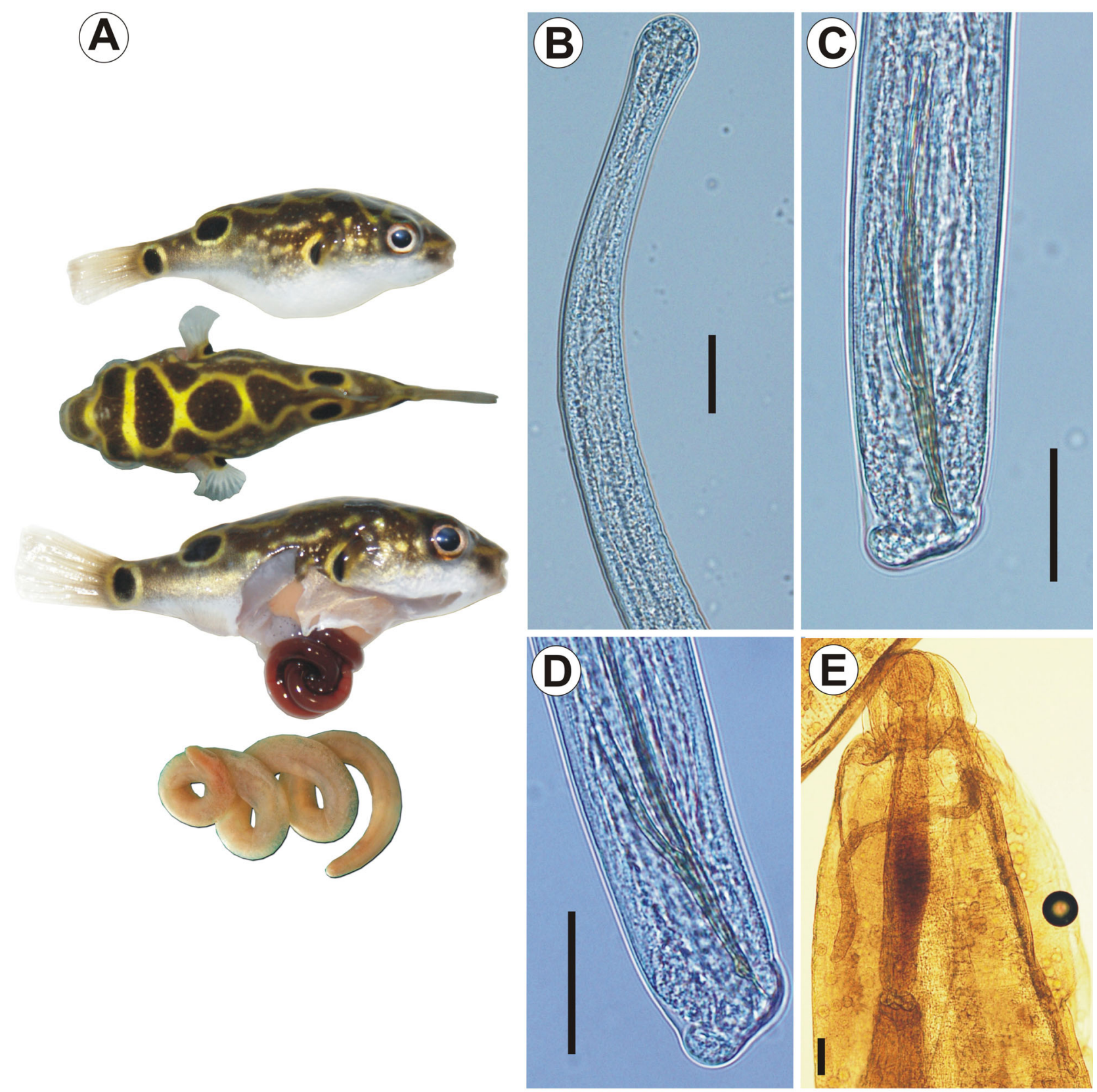

Fig. 1. A, Eyespot pufferfish Tetraodon biocellatus infected with Philometra thaiensis in its abdominal cavity; B, anterior end of $P$. thaiensis male; C, posterior end of male; D, posterior end of other male specimen; E, anterior end of gravid female. Scale bars (B-D, $30 \mu \mathrm{m} ; \mathrm{E}, 100 \mu \mathrm{m})$

3730XL genetic analyzer (Applied Biosystems, Japan). Molecular analyses of the partial sequences obtained were carried out using BioEdit version 7.0.4.1 (Hall, 1999) and MEGA 6 software (Tamura et al., 2013). Estimation of genetic distance and construction of evolutionary relationships among dracunculoids (Neighbor-Joining [NJ] tree) was carried out using Kimura 2-parameters (K2P) mode (complete deletion, bootstrap method, MEGA 6). The partial sequences were deposited and made available in the GenBank under accession numbers KC894067KC894071, FJ155811, and FJ161971-FJ161975.

\section{Results}

\section{Morphological study}

Philometridae Baylis et Daubney, 1926

Philometra thaiensis Moravec, Fiala et Dyková, 2004 (Figs. 1 - 3)

Male (3 specimens)

Body filiform, whitish, tapering at rounded posterior end; body tapers from mid-portion of body to anterior end near nerve ring area and slightly bulges at anteriormost end. Body 2.5 - $3.0 \mathrm{~mm}$ long; maximum width at mid-portion 
of body 35 - 36; minimum width near nerve ring area 20 24; width of cephalic end $25-28$, of caudal end in the lobular mound portion 29 - 30. Cuticle smooth. Cephalic end rounded, cephalic papillae very small, indistinct when viewed laterally. Oral aperture small. Oesophagus narrow, $242-263$ long, representing $8.8-9.7 \%$ of body length, with inflation at anterior end (length $23-31$, width $12-$ 14); length of anterior part of oesophagus $92-106$, that of posterior part overlapped by oesophageal gland $149-156$; minimum width of oesophagus at nerve ring area $6-8$; maximum width at mid-oesophageal gland $19-22$; posterior portion of oesophagus with well-developed, long oe-
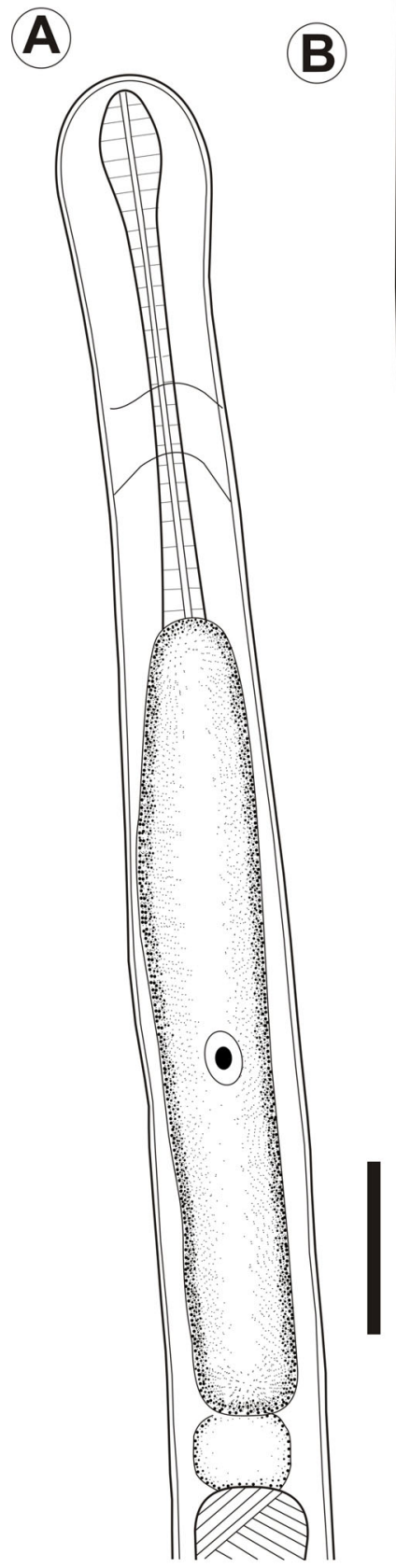

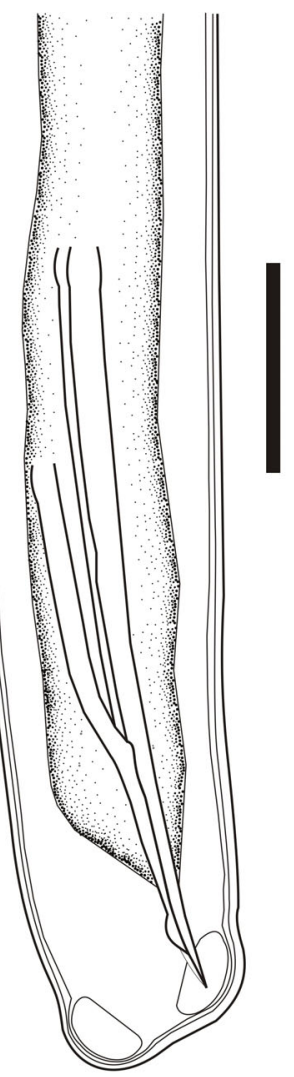

sophageal gland with large cell nucleus at middle, (6) in diameter. Oesophageal nucleus and nerve ring $150-195$ and $108-135$, respectively, from anterior extremity. Oesophagus opening into intestine through distinct valve. Ventriculus small, 15 long and $9-15$ wide. Intestine narrow, connected with genital tube to form the cloacal opening. Posterior end of body blunt, with broad, Ushaped, lobular mound and lightly visible caudal papillae. Spicules yellowish-brownish, slender, almost straight, needle-like, slightly unequal, with somewhat expanded proximal and sharply pointed distal tips; length of longer and shorter spicules $108-119$ and $105-121$, respectively,
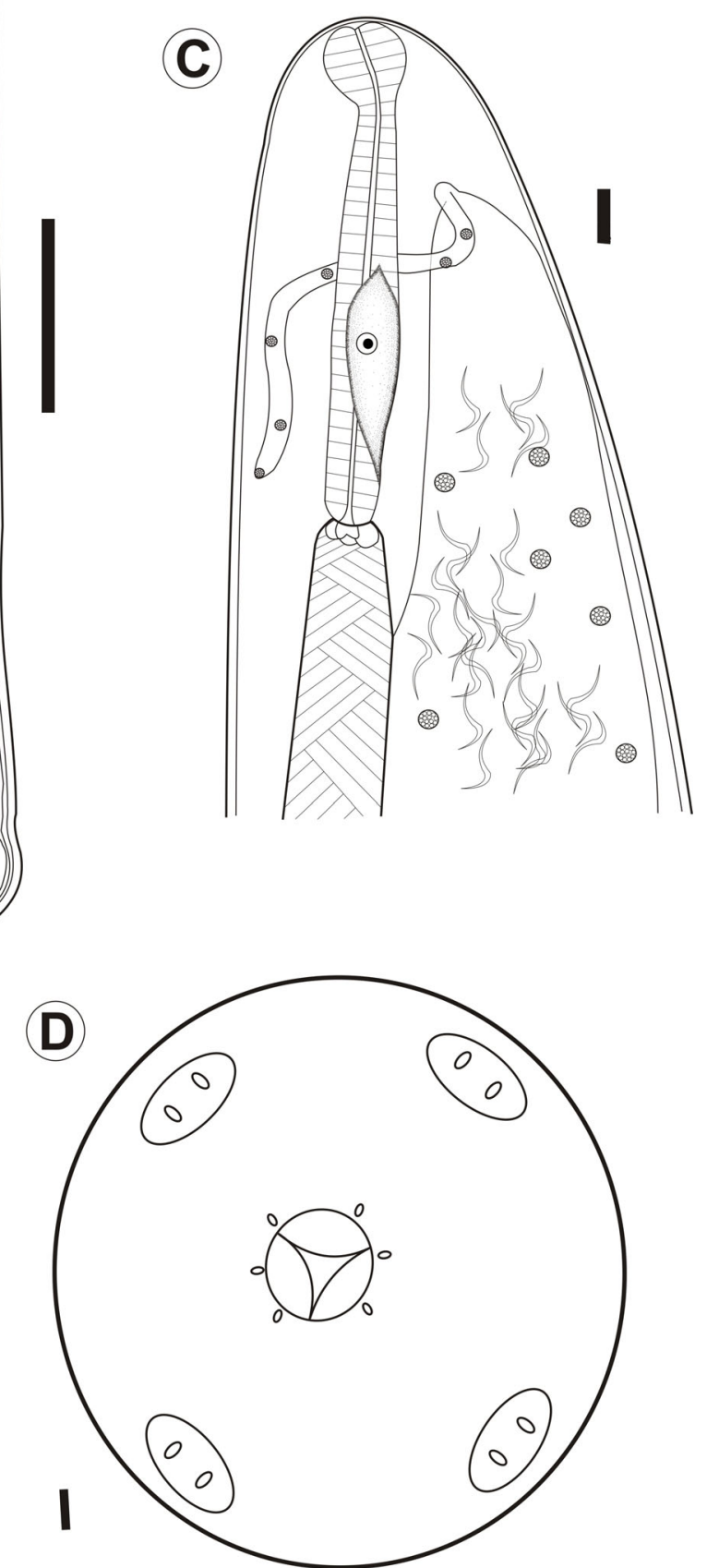

Fig. 2. Male and female of Philometra thaiensis from Tetraodon biocellatus. A, Anterior end of male; B, posterior end of male; C, anterior end of gravid female; D, cephalic end of gravid female. Scale bars (A, B = 30 $\mu \mathrm{m} ; \mathrm{C}=100 \mu \mathrm{m} ; \mathrm{D}=10 \mu \mathrm{m})$ 

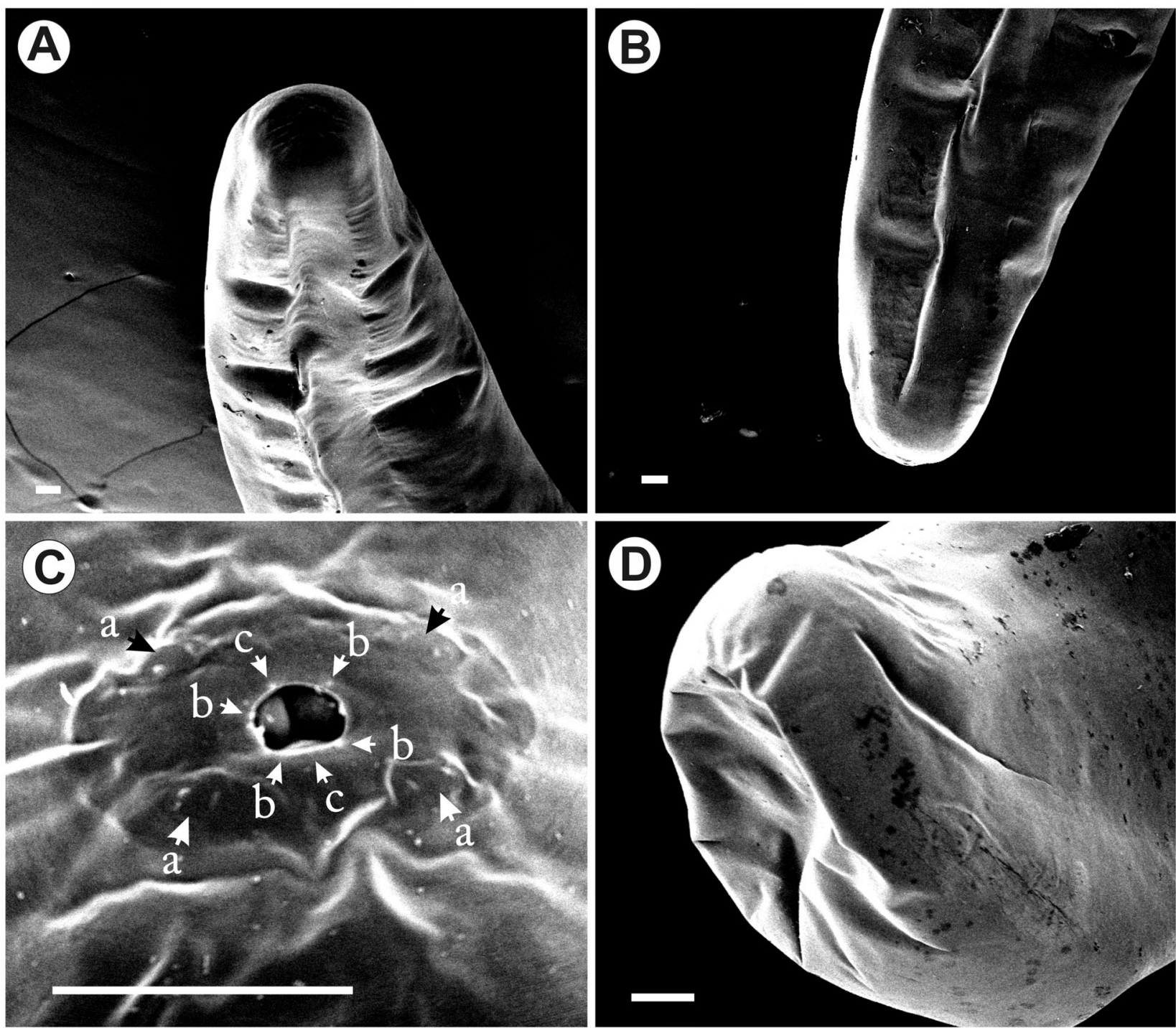

Fig. 3. Scanning electron micrographs (SEM) of Philometra thaiensis female. A, Anterior end; B, posterior end; C, cephalic end showing tiny cephalic papillae; D, closer view of posterior end without any caudal projections. Abbreviations: a, four paired submedian papillae of outer circle; b, four single submedian papillae of inner circle; c, single lateral papilla. (Scale bar: $100 \mu \mathrm{m}$ )

representing $4.0-4.3 \%$ of body length; spicule width at proximal end $5-7$; spicule width at middle 4 . Gubernaculum narrow, $69-77$ long, with approximately its proximal half dorsally bent; length of anterior bent part $35-40$, representing $50-54 \%$ of entire gubernaculum length; width of gubernaculum at proximal end $3-4$; maximum width of gubernaculum at bent portion 4; distal tip of gubernaculum pointed, with distinct reflected dorsal protuberance at distal end. Length ratio of gubernaculum to spicules 1:1.4 - 1.7. Spicule and gubernaculum well sclerotized.

Gravid female (5 specimens)

Body of live and fixed larvigerous specimens yellowish to reddish-brown, filiform, somewhat tapering at both ends; anterior end blunt, posterior end rounded without caudal projections. Cuticle smooth. Body length $25-43 \mathrm{~mm}$, maximum width at middle $1-2 \mathrm{~mm}$; maximum width/length ratio of body 1:23 - 28. Cephalic end, 163 wide; cephalic papillae very small, 7 in maximum width, indistinct when viewed laterally. Oral aperture small, 33 in diameter, oval; surrounded by four pairs of small submedian cephalic papillae of external circle, four single submedian papillae of internal circle, and single lateral papilla. Oesophagus, including anterior bulbous inflation $800-$ 1031 long, representing $2-4 \%$ of body length; bulb $123-$ 162 long and 132 - 169 wide; muscular oesophagus not covered by oesophageal gland 235 - 441 long; length of posterior part overlapped by oesophageal gland $447-638$; minimum width of oesophagus at nerve ring area $68-77$; maximum width at midportion of the oesophageal gland 121 - 153. Oesophageal gland not well demarcated, rather small, with distinct cell nucleus 46 in diameter and $529-$ 654 from anterior extremity. Nerve ring $191-269$ from anterior end of body. Oesophagus opening into intestine through distinct valve. Small ventriculus 59-103 long and $88-118$ wide present. Intestine narrow, ending blindly; its 
posterior end attached to body wall near caudal end by narrow ligament. Vulva and anus absent. Ovaries long, narrow, reflected, situated near both ends. Uterus filled with first-stage larvae and developing embryos.

Host: Eyespot pufferfish, Tetraodon biocellatus Tirant (Tetraodontiformes, Tetraodontidae); total length 10-12 cm; weight $60-80 \mathrm{~g}$.

Site of infection: Abdominal cavity.
Date of collection: April 2012.

Prevalence: $30 \%$ (3 fish infected out of 10 fish examined).

In te n s ity: Male parasites, $1-2$ per fish; female parasites, 1 per fish.

Locality: Thailand (fishes imported into Japan) (November 2011, April 2012).

Deposition of specimens: Meguro Parasitological Museum, Tokyo (M.P.M. Coll. No. 20901).

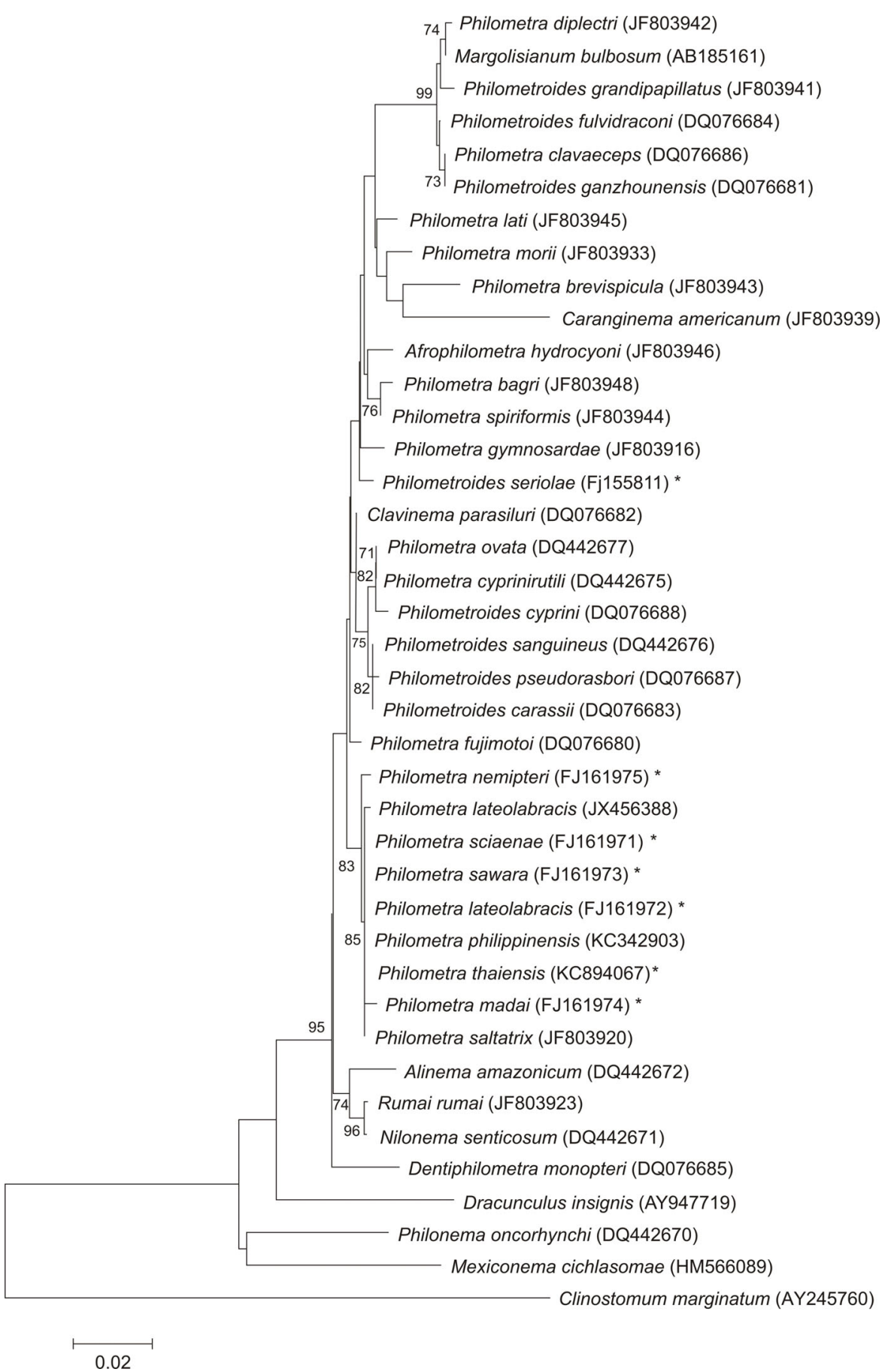

Fig. 4. Evolutionary relationships of the examined philometrid species (in asterisks) with other reported dracunculoids based on SSU 18S rRNA (Neighbor-Joining tree; Kimura 2-parameter; complete deletion; bootstrap method; MEGA 6) 
Table 1. Pairwise comparison of the genetic distances (Kimura 2-parameter mode) and number of nucleotide base differences (in parentheses) in the SSU 18S rRNA within the phylogenetic branch of the examined Philometra species (complete deletion; MEGA 6)

\begin{tabular}{|c|c|c|c|c|c|c|c|c|}
\hline Philometra species & 1 & 2 & 3 & 4 & 5 & 6 & 7 & $\begin{array}{l}\text { GenBank } \\
\text { Acc. No. }\end{array}$ \\
\hline $1 P$. thaiensis & & & & & & & & KC894067* \\
\hline 2 P. lateolabracis & 0 & & & & & & & FJ161972* \\
\hline 3 P. madai & $0.003(2)$ & $0.003(2)$ & & & & & & FJ161974* \\
\hline 4 P. sciaenae & 0 & 0 & $0.003(2)$ & & & & & FJ161971* \\
\hline 5 P. nemipteri & $0.003(2)$ & $0.003(2)$ & $0.006(4)$ & $0.003(2)$ & & & & FJ161975* \\
\hline 6 P. sawara & 0 & 0 & $0.003(2)$ & 0 & $0.003(2)$ & & & FJ161973* \\
\hline 7 P. saltatrix & 0 & 0 & $0.003(2)$ & 0 & $0.003(2)$ & 0 & & JF803920 \\
\hline 8 P.philippinensis & 0 & 0 & $0.003(2)$ & 0 & $0.003(2)$ & 0 & 0 & KC342905 \\
\hline
\end{tabular}

\section{Comments}

There is a high degree of host specificity among philometrid species, wherein species are characterized morphologically, including their location in the host (Moravec, 2006). Thus far, only six species of Philometra are reported from tetraodontiform fishes: P. balistii Rasheed, 1963 from the starry triggerfish Abalistes stellaris (Bloch et Schneider) and Balistes sp. (both Balistidae) (from Indian Ocean and Red and South China Seas); P. pellucida (Jägerskiöld, 1893) from the stellate puffer Arothron stellatus (Bloch et Schneider) (off Indonesia); P. robusta Moravec, Möller et Heeger, 1992 from the map puffer Arothron mappa (Lesson) (off the Philippines); P. thaiensis from $T$. palembangensis and the green pufferfish $T$. fluviatilis (Thailand); P. lagocephali Moravec et Justine, 2008 from the silver-cheeked toadfish Lagocephalus sceleratus (Gmelin) (off New Caledonia); and P. javaensis Moravec, Walter et Yuniar, 2012 from the immaculate puffer Arothron immaculatus (Bloch et Schneider) (off Indonesia). Except for P. balistii, which infects the oculo-orbits of its fish hosts, these Philometra species were located in the abdominal cavity of their host fishes, all belonging to the family Tetraodontidae (Moravec, 2006; Moravec et al., 1992; Moravec et al., 2004; Moravec \& Justine, 2008; Moravec et al., 2012).

In the current study, another freshwater ornamental fish, the eyespot pufferfish from Thailand, was found to be infected with nematodes belonging to the genus Philometra. Based on the total body length of females alone, the worms from the current study ( $25-43 \mathrm{~mm}$ in length) were not those of $P$. balistii $(110-210 \mathrm{~mm}), P$. pellucida $(132-$ $360 \mathrm{~mm})$, or $P$. robusta $(275-450 \mathrm{~mm})$. In spite of similar total body sizes to $P$. lagocephali $(52.6 \mathrm{~mm})$ and $P$. javaensis $(33-54 \mathrm{~mm})$, the current samples were neither the former nor the latter species because of the following major differences: host's environment (freshwater vs. marine); oesophageal gland (not well demarcated, rather small vs. large $[P$. lagocephali]); amphids (hardly visible vs. large $[P$. lagocephali]); and distance of cephalic papillae of external circle in each pair (closely located vs. relatively far $[P$. javaensis $])$. In this regard, the current female philometrids were morphologically confirmed to be $P$. thaiensis based on their morphological similarities with the reported gravid female of that species (Moravec et al., 2004, 2012; Moravec \& Justine, 2008). Although the males were not found from the host fishes by Moravec et al. (2004), the identity of the site of infection (abdominal cavity), the same country of origin (Thailand), aquatic environment (freshwater), and the genus of the host fish (Tetraodon), in addition to the considerable morphological similarity of $P$. thaiensis described (Moravec et al., 2004), indicate that the species of Philometra males from the eyespot pufferfish is $P$. thaiensis. Hence, this study reports $P$. thaiensis for the first time from the eyespot pufferfish, which is a new host

Table 2. Pairwise comparison of the genetic distances and number of nucleotide base differences (in parentheses) in the SSU 18S rRNA between the examined Philometroides seriolae from the current study with other Philometroides species deposited in GenBank (Kimura 2-parameter mode; complete deletion; MEGA 6)

\begin{tabular}{|c|c|c|c|c|c|c|c|c|}
\hline Philometroides species & 1 & 2 & 3 & 4 & 5 & 6 & 7 & $\begin{array}{l}\text { GenBank } \\
\text { Acc. No. }\end{array}$ \\
\hline 1 P. seriolae & & & & & & & & FJ155811* \\
\hline 2 P. pseudorasbori & $0.022(18)$ & & & & & & & DQ076687 \\
\hline $3 P$. sanguineus & $0.024(20)$ & $0.008(7)$ & & & & & & DQ442676 \\
\hline 4 P. carassii & $0.021(17)$ & $0.001(1)$ & $0.007(6)$ & & & & & DQ076683 \\
\hline 5 P. cyprini & $0.022(18)$ & $0.007(6)$ & $0.013(11)$ & $0.006(5)$ & & & & DQ076688 \\
\hline 6 P. grandipapillatus & $0.036(29)$ & $0.033(27)$ & $0.029(24)$ & $0.032(26)$ & $0.033(27)$ & & & JF803941 \\
\hline 7 P. fulvidraconi & $0.033(27)$ & $0.031(25)$ & $0.033(27)$ & $0.029(24)$ & $0.033(27)$ & $0.015(12)$ & & DQ076684 \\
\hline 8 P. ganzhounensis & $0.033(27)$ & $0.027(22)$ & $0.031(25)$ & $0.026(21)$ & $0.029(24)$ & $0.011(9)$ & $0.007(6)$ & DQ076681 \\
\hline
\end{tabular}

* This study 
record. In addition, further morphometrical data presented for female $P$. thaiensis extend the intraspecific variability of this species. Since no Philometra males have been reported from any of the above-mentioned tetraodontiform fishes, the male $P$. thaiensis cannot be compared morphologically.

\section{Molecular study}

Molecular data on the SSU 18S rRNA confirmed that the males isolated from the eyespot pufferfish were genetically similar to morphologically identified female $P$. thaiensis. In addition, molecular examinations of five Philometra species ( $P$. lateolabracis, $P$. madai, P. nemipteri, $P$. sawara, and $P$. sciaenae) and one Philometroides species ( $P$. seriolae) from the current study revealed their evolutionary relationships with $P$. thaiensis and other reported dracunculoids in the GenBank. Based on the generated evolutionary (NJ) tree, the six Philometra species examined grouped into one major clade with very low genetic variations among each other (K2P value of $0.000-0.006$; nucleotide bases difference of $0-4 \mathrm{bp}$ ) (Fig. 4; 1). The only gonad-infecting philometrid that did not group within this clade is the deposited P. clavaeceps (DQ076686), whereas $P$. thaiensis is the only species within the clade that infects the abdominal cavity. Furthermore, the NJ tree revealed that Philometroides seriolae is genetically close (K2P values; number of nucleotide bases difference) to the following Philometroides species: P. carassii $(0.021 ; 17$ bp), P. cyprini ( $0.022 ; 18$ bp), P. pseudorasbori $(0.022 ; 18$ $\mathrm{bp})$, and $P$. sanguineus $(0.024 ; 20 \mathrm{bp})$ (Fig. 4; Table 2). Generally, the NJ trees showed no clear separation between the genera Philometra and Philometroides, whereas there were Philometra species ( $P$. clavaeceps, $P$. cyprinirutili, $P$. diplectri, and $P$. ovata) that joined the clade of Philometroides species. It was also observed that the positions of the genus Margolisianum (genus inquirendum) and the genera Clavinema, Caranginema, and Afrophilometra are in the Philometra/Philometroides groupings, which indicates that either these genera are possibly closely related to the genus Philometra or Philometroides, or these genera cannot be clearly differentiated using this gene region.

\section{Discussion}

Morphological and molecular data confirmed that the male Philometra species isolated from $T$. biocellatus is that of the reported $P$. thaiensis from its type host $T$. palembangensis and T. fluviatilis (Moravec et al., 2004). Sometimes it is difficult to morphologically differentiate closely related species, relying mainly on female specimens, leading to taxonomical confusion and misidentifications. Although no philometrid males have previously been described from the reported tetraodontiform fishes, morphological differences among females are sufficient to verify that the examined Philometra species from T. biocellatus is $P$. thaiensis. With the discovery of additional Philometra species from tetraodontiform fishes, relying on female specimens would not be enough, thus requiring the discovery of conspecific males for species comparison and identification. On the other hand, Quiazon et al. (2008a,b) have reported five gonad-infecting Philometra species $(P$. lateolabracis, $P$. madai, $P$. nemipteri, $P$. sawara, and $P$. sciaenae) from Japanese waters, where taxonomic positions based on the molecular data on the ITS region have been examined. Since ITS sequences for other dracunculoids are limited, molecular examinations of these Philometra species targeting the SSU 18S rRNA have revealed their evolutionary relationships with other dracunculoid species available in the GenBank.

Molecular taxonomy has raised some major points regarding the taxonomical positions of some genera within the dracunculoids. Despite the diverging ideas among different reports on the taxonomical relationship between Philometra and Philometroides species, a common conclusion remains that the genera Philometra and Philometroides should be re-evaluated and that the importance of using molecular tools in parallel with morphological identification cannot be overemphasized for philometrids (Moravec $\&$ de Buron, 2013). The suggestion of re-evaluation is strongly supported by the generated phylogenetic tree in the present study, wherein no clear separation between other Philometra spp. and Philometroides spp. exists. This also coincides with previous reports, in spite of the differences in the target gene examined (Quiazon et al., 2008a,b; de Buron et al., 2011). It was also confirmed that Philometridae is paraphyletic with a clear separation of Philonema from the philometrids, similar to previous reports (Wijová et al., 2006; Černotíková et al., 2011).

Two species of two different genera, which were later described as Philometra overstreeti Moravec et de Buron, 2006 and Philometroides paralichthydis Moravec et de Buron, 2006, were confused under the name Margolisianum bulbosum (Blaylock and Overstreet, 1999; Moravec $\&$ de Buron, 2006). The inclusion of Margolisianum (genus inquirendum) within the Philometra and Philometroides clade, as also reported by Quiazon et al. (2013), indicates that the genus Margolisianum is identical either with the genus Philometra or Philometroides. In addition, Clavinema fujimotoi (syn. Philometra fujimotoi) has a separate branch from other groups of Philometra spp., and its evolutionary position is close to Clavinema parasiluri, thus, confirming the transfer of the previously identified $P$. fujimotoi to the genus Clavinema. However, the position of the genus Clavinema within the Philometra and Philometroides groups raises the taxonomic question of its proper identity, thereby necessitating a re-evaluation of this genus. There is also a need to verify the taxonomic position of Philometra brevispicula, as this species is grouped with Caranginema, a group far distant from the genus Philometra. In conclusion, the identification of males of other philometrids, which should be supported by molecular data, is needed for the suggested re-evaluation of this group of nematodes, which are of social, economic, and scientific importance. 


\section{Acknowledgements}

This study was partly supported by the Japan Society for the Promotion of Science (JSPS) Postdoctoral Fellowship for Foreign Researchers and a Grant-in-Aid for JSPS fellows (23-01405).

\section{References}

Blaylock, R. B., Overstreet, R. M. (1999): Margolisianum bulbosum n.gen., n.sp. (Nematoda: Philometridae) from the southern flounder, Paralichthys lethostigma (Pisces: Bothidae), in Mississippi Sound, USA. J. Parasitol., 85: 306 - 312. DOI: 10.2307/3285639

Černotíková, E., HorÁk, A., Moravec, F. (2011): Phylogenetic relationships of some spirurine nematodes (Nematoda: Chromadorea: Rhabditida: Spirurina) parasitic in fishes inferred from SSU rRNA gene sequences. Folia Parasitol., 58: 135 - 148. DOI: 10.14411/fp.2011.013

De Buron, I., France, S. G., Connors, V. A., Roumillat, W. A., Tsoi, L. C. (2011): Philometrids of the southern flounder Paralichthys lethostigma: a multidimensional approach to determine their diversity. J. Parasitol., 97: 466 - 475. DOI: 10.2307/23019109

Froese, R., Pauly, D. (Eds). (2014): FishBase. World Wide Web electronic publication, www.fishbase.org, version $6 / 2014$

GAMBHIR, R. K., NG, Z. (2014): A new nematode of the family - Philometridae from a catfish in Manipur, India. $J$. Exp. Zool. India, 17: 111 - 114

HALL, T. A. (1999): BioEdit: a user-friendly biological sequence alignment editor and analysis program for Windows 95/98/NT. Nucl. Acids. Symp. Ser., 41: 95 - 98

Moravec, F. (2006): Dracunculoid and anguillicoloid nematodes parasitic in vertebrates. Academia, Prague, 634 pp. MorAveC, F. (2014): Systematic status of Piscinema barakensis [sic] Gambhir et Ng, 2014 (Philometridae) and Rhabdochona carpiae Nimbalkar, Deolalikar et Kamtikar, 2013 (Rhabdochonidae), two nematodes recently described from freshwater fishes in India. Folia Parasitol., 61: 266. DOI: $10.14411 / \mathrm{fp} .2014 .045$

Moravec, F., Ali, A.H. (2014): Additional observations on Philometra spp. (Nematoda: Philometridae) in marine fishes off Iraq, with the description of two new species. Syst. Parasitol., 87: $259-271$

Moravec, F., De Buron, I. (2006): Two new species of philometrid nematodes (Nematoda: Philometridae) from the southern flounder Paralichthys lethostigma in the estuaries of South Carolina, USA. Folia Parasitol., 53: 139 146. DOI: $10.14411 /$ fp.2006.018

Moravec, F., De Buron, I. (2013): A synthesis of our current understanding of philometrids (Philometridae), a group of growingly important fish parasites. Folia Parasitol., 60: 81 - 101. DOI: 10.14411/fp.2013.010

Moravec, F., Fiala, I., DyKovÁ, I. (2004): Philometra thaiensis sp. n. (Nematoda: Philometridae) from Tetraodon palembangensis and T. fluviatilis (Pisces) from fresh waters in Thailand, with a key to Philometra spp. parasitic in the host's abdominal cavity. Acta Parasitol., 49: 319 - 324 Moravec, F., Justine, J.-L. (2008): Some philometrid nematodes (Philometridae), including four new species of Philometra, from marine fishes off New Caledonia. Acta Parasitol., 53: 369 - 381. DOI: 10.2478/s11686-008-0050-7 Moravec, F., Khosheghbal, M., Pazooki, J. (2013): Two philometrids (Nematoda: Philometridae) infecting the tigertooth croaker Otolithes ruber (Bloch \& Schneider) (Teleostei: Sciaenidae) off Iran, including erection of a new genus. Syst. Parasitol., 86: 33 - 41. DOI: 10.1007/s11230-013-9430-y

Moravec, F., Möller, H., HeEger, T. (1992): Philometra robusta sp. n. (Nematoda: Philometridae) from the abdominal cavity of the scribbled toadfish, Arothron mappa (Lesson) from the Philippines. Folia Parasitol., 39: 227 - 234

Moravec, F., Walter, T., Yuniar, A. T. (2012): Five new species of philometrid nematodes (Philometridae) from marine fishes off Java, Indonesia. Folia Parasitol., 59: 115 - 130. DOI: 10.14411/fp.2012.017

Nadler, S. A., Carreno, R. A., Mejia-Madrid, H., Ullberg, J., Pagan, C., Houston, R., Hugot, J.-P. (2007): Molecular phylogeny of clade III nematodes reveals multiple origins of tissue parasitism. Parasitology, 134: 1421 - 1442. DOI: 10.1017/S0031182007002880

Quiazon, K. M. A., Yoshinaga, T. (2013): Gonad-infecting philometrid Philometra philippinensis sp. nov. (Nematoda, Philometridae) from bigeye barracuda Sphyraena forsteri Cuvier (Sphyraenidae) off Mariveles, Bataan Province, Philippine archipelago. Acta Parasitol., 58: 504 - 514. DOI: 10.2478/s11686-013-0165-3

Quiazon, K. M. A., YoshinaGA, T., OGAWA, K. (2010): Taxonomical note on the redescription of Philometroides seriolae (Ishii, 1931) infecting Japanese amberjack (Seriola quinqueradiata Temminck et Schlegel, 1845) in Japan. J. Tropical Biol., 8: $29-34$

Quiazon, K. M. A., Yoshinaga, T., Ogawa, K. (2008a): Taxonomical study into two new species of Philometra (Nematoda: Philometridae) previously identified as Philometra lateolabracis (Yamaguti). Folia Parasitol., 55: 29 41. DOI: $10.14411 / \mathrm{fp} .2008 .005$

Quiazon, K. M. A., Yoshinaga, T., Ogawa, K. (2008b): Philometra sawara sp. n. and a redescription of Philometra sciaenae Yamaguti, 1941 and Philometra nemipteri Luo, 2001 (Nematoda: Philometridae): a morphological and molecular approach. Folia Parasitol., 55: 277 - 290. DOI: 10.14411/fp.2008.036

Tamura, K., Stecher, G., Peterson, D., Filipski, A., KUMAR, S. (2013): MEGA6: Molecular Evolutionary Genetics Analysis version 6.0. Mol. Biol. Evol., 30: 2725 2729. DOI: $10.1093 / \mathrm{molbev} / \mathrm{mst} 197$

Van Megen, H., Van Den Elsen, S., Holterman, M., Karssen, G., Mooyman, P., Bongers, T., Holovachov, O., BAKKER, J., HELDER, J. (2009): A phylogenetic tree of nematodes based on about 1200 full-length small subunit ribosomal DNA sequences. Nematology, 11: 927 - 950. DOI: $10.1163 / 156854109 X 456862$

WijovÁ, M., Moravec, F., HoraK, A., Lukeš, J. (2006): Evolutionary relationships of Spirurina (Nematoda: Chro- 
madorea: Rhabditida) with special emphasis on dracunculoid nematodes inferred from SSU $r$ RNA gene sequences. Int. J. Parasitol., 36: 1067 - 1075

RECEIVED APRIL 15, 2014
Wu, S.-G., Wang, G.-T., Li, W.-X., Nie, P. (2005): A preliminary study on phylogeny of nine species of philometrids in China. Hydrobiol. Sin., 29: 571 - 575 